\title{
Perbedaan Pendapat di Sekitar Kedatangan Agama Islam di Indonesia
}

\section{Suwedi Montana}

Keywords: history, diaspora, research, Islam

\section{How to Cite:}

Montana, S. Perbedaan Pendapat di Sekitar Kedatangan Agama Islam di Indonesia. Berkala Arkeologi, 14(2), 123-128. https:/ / doi.org/10.30883/jba.v14i2.711

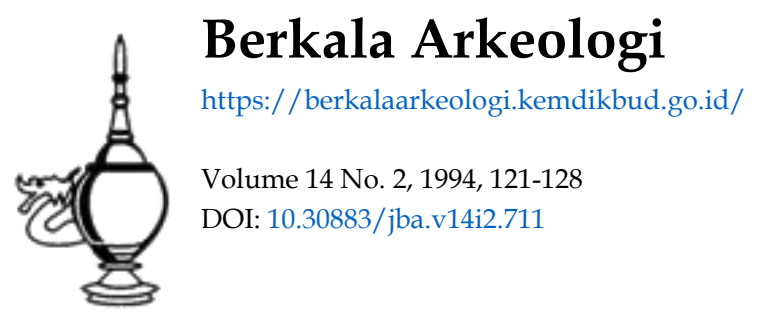

\section{cc) (7) (2)}

This work is licensed under a Creative Commons Attribution-NonCommercial-ShareAlike 4.0 International License. 


\title{
PERBEDAAN PENDAPAT DI SEKITAR KEDATANGAN AGAMA ISLAM DI INDONESIA
}

\author{
Suwedi Montana \\ (Pusat Penelitian Arkeologi Nasiona!)
}

\begin{abstract}
Pendahuluan
Pengertian kedatangan dı sını ıalah penyebaran awal agama Islam di Indonesia. Penyebaran tersebut dapat bersifat perorangan ataupun kelompok. Apabila pelakunya suatu kelompok orang, konsekuensinya merupakan suatu organisasi. Pelaku yang bersifat organisası dapat dikendalikan oleh pimpinan negara tertentu (bersifat politis) atau organisasi bebas dalam arti tidak terikat oleh tali kendali sebuah negara Sedangkan yang bersifat perorangan penyebarannya bergantung pada sikap, tingkah laku dan gaya kepemimpinan orang tersebut.

Kedatangan agama Islam di Indonesia telah banyak diperdebatkan dan sering diseminarkan. Di Medan dan Aceh hampir dalam dua dekade diseminarkan masalah tersebut tiga kali berturut-turut. Dı Medan dan di Banda Aceh telah diadakan pada tahun 1963 dan 1978, dan seminar ketiga diadakan di Perlak pada tahun 1981 Sementara itu para pakar lain baik seorang orientalıs darı akhır abad XIX dan awal abad XX maupun para pakar sejarah dan agama Islam di Indonesıa dan peneliti bebas laınnya secara perorangan mengadakan penelitian tentang masuk dan kedatangan agama Islam di indonesia. Mereka dengan bebas menyatakan hasil penelitiannya itu Oleh karenanya daiam tulisan ini akan dilihat sampa: seberapa jauh keterkaitan pendapat dan pandangan tersebut dengan membuktikannya dalam argumentasi yang meyakinkan
\end{abstract}

\section{Agama Islam datang ke Indonesia langsung dari Tanah Arab dan didakwahkan oleh orang Arab}

Agama Islam berkembang setelah melalui upaya. Ikhtiar. dan perjuangan yang berat. Tidak begitu saja orang mau menerima agama baru itu sebelum mengetahui kebaikan ajarannya. Oieh karenanya baru pada abâd ke-8 syiar Islam me luas ke barat dan ke timur. Ke barat sampal ke pantai barat Eropa dan ke timur sampai ke Timur Jauh. Persebaran ke timur hingga saat ini masih dipertanyakan apakah dilakukan oleh orang Arab ataukah non Arab. Argumen yang kuat untuk menetapkan siapa dan dari mana penyiar agama itu perlu dikemukakan sebagai bukti. Apakah orang Arab langsung menyiarkan ke Cina dan kemudian ke Indonesia, atau secara estafet disebarkan oleh orang Arab ke Parsi, kemudian orang Parsi meny'ebarkan ke india, dan selanjutnya muslım India ${ }^{1}$ menyiarkan Islam ke timur hingga sampai ke Nusantara terutama Sumatra panta! tımur Hal ini perlu dipertimbangkan

Bagaimana cara penyebarannya apakah dengan damal, luwes, atau dengan paksaan yang menimbulkan kekerasan?, cara-cara sepertı itu pun masih teka-teki meskipun ada surah di dalam Quran mengandung perintah tentang dasar-dasar dakwah dan sikap islam terhadap lawan "Serulah (manusia) kepada jaian Tuhanmu dengan hikmah dan bantahlah dengan cara yang baik. Sesungguhnya Tuhanmu Dialah yang lebsh mengetahui tentang sıapa yang tersesat darı jalan-Nya dan Dialah yang lebih mengetanul orangorang yang mendapat petunjuk (An Nahl: 125)

Seminar sejarah masuk dan berkembangnya Islam di Indonesia yang ke 3 tahun 1981 di Perlak menetapkan beberapa kesimpulan. Antara laın menyatakan agama Islam telah masuk ke Nusantara pada abad $1 \mathrm{H}$ langsung darı tanah Arab (A. Hasymi, 1981:52). Kesimpulan tersebut bernada keras sebagal bantahan terhadap pendapat-pendapat lain tentang kedatangan agama islam di indonesia Dasar-dasar dalam pengam. bilan kesimpulan didasarkan pada beberapa makalah yang disemınarkan, antara lain sbb

Teorl tentang datangnya Islam di Indonesıa

1. Datang secara langsung dari Negeri Arab dengan pertimbangan karena muslim alam Melayu berpegang dengan Mazhab Syafi'ı yang lahir di Semenanjung Arab

2. Datang dari India yaitu dengan adanya hubungan perniagaan yang teguh antara India dengan gugusan pulau-pulau Melayu

3. Datang dari Cina, teorl ini dikemukakan oien Emanuel Godinho de Eradie pada tahun 1613 "Sesungguhnya aqidah Muhammad telah diterima Patani dan Pamdi Pantaı Timur Kemudian diterıma dan diperkembangkan oler permaisuri (yaitu Paramesywara) ds tahun 1411 (lihat Wan Hussein Azmi Islam masuk dan berkembang hingga abad $X V$ dalam A. Hasymi 1981-174-216)

Inti darı ketiga teori tersebut menunjukkan bahwa tanah Arab sebagal tempat kelahiran agama Islam. Adapun pelaku penyıar Isiam tidak

\footnotetext{
1 Muslim india pada abad XV-XVI dikenal sebaga orang Moor
} 
didefinitifixan orang Arab. Dengan kata lain penyebaran agama dilakukan secara langsung dari tanah Arab ke Indonesia (Sumatra, Malaka) atau melaluı Cina dengan jalan perdagangan routenya adalah sbb

1. Arab - Gugusan Pulau Melayu - Asia Tenggara,

2. Arab - India - Gugusan Pulau Melayu, dan

3 Arab - Khurasan (Parsi) - Khutan - Gobi - Sangtu - Nan-Syau - Gugusan Pulau Melayu

Pandangan di atas itu memang benar, tetapi belum memecahkan masalah siapa yang menyiarkan ke kepulauan Nusantara, apakah mubaligh-mubaligh Arab profesional ataukah MollahMollah non Arab yang dibawa oleh saudagarsaudagar Arab?

Pada bagian lain telah disinggung metoda islamisasi dilakukan secara perorangan dan secara resmi (politis). Islamisasi secara perorangan dılakukan oleh orang seorang yang datang pada suatu tempat yang masyarakatnya masih memeluk agama lama (Hindu, Buda). Orang itu belum berani secara terbuka menyatakan dirinya seorang muslim dan bemiat akan mengislamkan masyarakat, karena masyarakat dı sekelilingnya masih beragama lain yang menjadi agama resmi Hal tersebut dapat diquktikan dengan makam Fatımah bınti Maimun. ${ }^{2}$ Fatimah adalah seorang muslımah yang datang ke Gresik (Jawa Tmur) pada abad $5 \mathrm{H}$, dan meninggal pada tahun $475 \mathrm{H}$ (1082 M). Desa tempat ditemukannya makam Fatımah dinamakan juga Desa Leran. Leran atau Liran adalah nama sebuah tempat di dekat Khurasan. Parsı. Dengan demikian kalau Leran itu nama tempat di Parsi boleh jadi Fatimah itu memang datang darı sana. Selanjutnya kalau Fa. timah menınggal pada tahun $475 \mathrm{H}$ di Gresik berarti beberapa lama sebelum tahun itu sudah ada orang muslim di Gresik. Dan dia datang tidakJah seorang diri sebab dia seorang perempuan, ini mengandung makna pula bahwa di Gresik sudah ada kelompok muslim sebelum tahun 1082, padahal pada periode itu agama Hindu dan Budha dalam kondisi puncak. Sesual dengan perintah dalam Ouran (0.16:125), orang-orang muslim itu mengadakan dakwah secara perorangan, sehingga kemungkinan penyiaran agama Islam di Desa Leran adalah mubaligh atau mollah dari Parsi.

Islamisasi secara resmi melalui pendekat. an terhadap penguasa (raja), atau adipati yang menurut istilah Tome Pires disebut pate Saudagar-saudagar muslim dibantu oleh para mollah dan membujuk para penguasa dengan berbagai hadiah, upeti, atau pemberian lainnya. Pendekatan kepada penguasa itu mempunyai dua keuntu-

\footnotetext{
$\overline{2}$ Oleh penduch warito ini dikenal Demama Puri Leran atau Putui Swayi
}

ngan; saudagar-saudagar musìm akan memperoleh fasilitas dari penguasa (motif ekonomi), dan jika penguasa itu sudah memeluk agama Isiam maka secara politis seluruh penduduk akan menjadi muslim pula. Karena biasanya ada proklamasi dari penguasa supaya rakyatnya beralih kepercayaan ke Islam seperti yang dipeluk oleh penguasa tersebut. Contoh tentang peristiwa islamisasi secara politis itu dapat disimak dalam Sejarah Melayu, setelah Sultan Muzafarsyah menjad, muslim, seisi istana masuk Islam. Pada abad XVII di Kerajaan Goa (Sulawesi Selatan), raja beralih ke agama Islam dan memproklamasıkan supaya seluruh rakyat kerajaan memeluk agama Islam.

Hal sepert! itu mudah dilakukan di Indonesıa karena sifat paternalistik sudah mendarahdaging dalam tubuh masyarakat, sehingga apa kata pemımpin itulah yang dianggap benar dan harus diturut. Dengan kata lain panutan sangat menentukan dalam islamisası politis of indonesia. Contoh lebih aktual mengenai sifat paternaIstik masyarakat Jawa dapat dilihat pada peris. tiwa Kristenisasi pada tahun 1876 di sebuah desa di Kabupaten Purworejo, Jawa Tengah Seorang kyai bernama Raden Abbas memimpin sebuah pesantren yang santrinya berjumlah ribuan tersebar sampai ke wilayah selatan Pekalongan Kyai Abbas sangat anti terhadap penyebaran agama Kristen di wilayah Purworejo yang disırkan oleh pendeta Belanda bernama Phillip. Kya Abbas mendatangi pendeta itu dan menggelar perbıncangan yang pada intınya Kyai tidak suka akan adanya penyebaran agama Kristen. Perbıncangan sampal pada suatu kondisı yang sangat menentukan apakah Pendeta Phillip akan menghentikan syiar agamanya dan meninggalkan wilayah Pumorejo jika tidak dapat memecahkan sebuah masalah yang diajukan oleh Kyal Abbas Sebaliknya Kyai Abbas akan bersedia "necep ngeimu" dari pendeta itu jıka pendeta berhasi memecahkan masalah tersebut In perjanjian yang sangat fatal sebab berarti Kya Abbas akan beralih agama demi harga dirinya Masalah yang dikemukakan itu adalah masalah tassawut yang rumit. Tetapi Kyai Abbas tidak menyadarı bahwa pendeta itu adalah ahlı Islamologi dan seorang orientalis, sehingga masalah rumit yang dikemukakan oleh Kyal Abbas dapat dipecahkan dan Kyai Abbas memenuhi janjinya... Kyai Abbas kemudian dibaptis sebagai Kyai Zadrach (Zadrach adalah nama seorang pendeta Babylonı yang pertama-tama masuk Kristen). Setelah Kyai Abbas atau Zadrach menjadi Kristen maka santrinya banyak pula yang masuk Kristen, padanal selama bertahun-tahun Pendeta Phillip bertugas baru dapat mengkristenkan jemaat Jawa dengan 
hitungan jarı. Sampaı sekarang mesjıd dari bekas Pesantren Kyal Abbas masih berdiri tetapi sudah beralih fungsı menjadi gereja sejak peristiwa itu (thinat Claude Gullot, LAffiar de Zadrach, dalam Archipel)

\section{Bagaimana Islamisasi di Jawa?}

Hubungan dagang antara Malaka dan Jawa frekuensinya lebih besar daripada dengan pantai tımur Sumatra (Pasaı), meskıpun pertumbuhan agama Islam di Pasal lebıh awal. Informasi Tome Pires menyebutkan berikut. "Pada saat ini Raja Xaquem Darxa (Muzafarsyah) sudah tua, dan negara sedang ramai dengan perdagangan, banyak orang Moor serta Mollah yang mencoba keras mengisiamkan raja tersebut, dan Raja Pasai sangat ingin... Pada akhimya ketika berumur 72 hun Raja Xaquem Daixa masuk Islam dengan seluruh penghuni istananya dan kawin dengan putri Raja Pase" (Cortesao, 1944:242). Berita Tomes Pires tersebut memberikan beberapa petunjuk yang penting. Pertama, harus dibedakan antara pedagang Moor dan Mollah. Golssary Hobson-Jobson mengartikan Moor A Mahommedan; and so from the habitual use of the term (Mouro), by the Portuguese in India, particularly a Mahommedan inhabitant in India (Col. Henry Yule, 1903: 581). Uraian tersebut menjelaskan yang dimaksud pedagang Moor adalah pemeluk agama Islam di India; sementara itu Mollah (Arab maula= tuan) adalah khas istilah Parsi yang berarti guru agama. Kedua, mengutamakan orang Arab sebagai guru agama, sebab mereka dianggap lebih mengetahui masalah agama. Dan ketiga, sasaran dakwah diutamakan kepada penguasa sehıngga Islam menjadi kokoh dan sejahtera, yang selanjutnya islamisasi berjalan lancar dan cepat

Di Jawa, yang menjadi sasaran islamisasi adalah para pate (Adipati, Patih). Di pesisir utara orang-orang Moor berdomisili selama 70 tahun $^{3}$ ketika menggantikan kekuasaan di Jawa (lbid, 182-277). Perlu diingat bahwa pemakaman kuna Tralaya di Trowulan terdanat batu nisan berangka tahun Jawa kuna yang jika dikonversikan menjadi tahun 1376 dan 1388,1401,1418,1429,1467 (dua buah makam lihat: Damais 1954 :411). Bukti tersebut menunjukkan bahwa di pedalaman Jawa orang muslim sudah berdomisili, dan kemungkinan mereka adalah pejabat keraton. Hal tersebut tampak jelas pada hiasan medali Surya Majapahit yang terukir pada ketujuh makam. SeIain itu hasil penelitian Endang Sri Hardiyati dan Suwedi Montana di Ketapang. Kalimantan Barat

3 Masa pemenntahan Sulten Muzafarsyah diperkirakan tahun 1450, maka 70 tahun sebelumnya adalah tahun 1380 berhası menemukan 7 buah batu nısan pada kubur kuna di bekas Kerajaan Tanjungpura berangka tahun Jawa kuna 1418, 1426, 1454 (dua buah makam), 1437, dan 1441 (dua buah makam). Tipe batu nisan Majapahit (Tralaya) dengan hiasan medali lambang solell de Majapahit, lambang kebesaran Majapahit. Makam tersebut kemungkinan merupakan makam pejabat keraton Tanjungpura, jika dilihat hıasan medali kemungkinan kerabat keraton Majapahit. Darı data tersebut dapat disimpulkan bahwa islamisası di Ketapang sezaman dengan islamisasi di pedalaman Jawa (Majapahit)

Siapa pembawa agama Islam hıngga sampai ke Sumatra dan Jawa?. Pase di Aceh Utara dengan rajanya Malik al Saleh meninggal tahun 1297 didasarkan pada batu nisannya. Batu nisan tersebut merupakan barang fabricated buatan Cambay, kota pelabuhan di Guzerat, pantaı India barat. Produksi nisan Cambay ini juga dipakai pada nisan makam Malik Ibrahim (tercatat wafat tahun 1419, kemungkinan beliau adalah salah seorang dari Wali Sanga yang tertua) di Gresik.

Sultan Malik al Saleh ${ }^{4}$ diperkirakan sudah memluk agama Islam tahun 1290-an, tetapi siapakah yang mengislamkan sultan? Untuk itu perlu disimak Hikayat Raja-Raja Pasai dan Sejarah Melayu yang mengisahkan tentang sebuah kapal dari Malabar dengan penumpang ulama muslim, Mollah

Malabar adalah sebuah kota di Pantaı Coromandel tempat tınggal orang-orang berbahasa Tamil di India Seiatan (lihat Robson 1981, BK1 $137: 272)$. Kontak India selatan dengan Islam terjadi lebih awal daripada dengan India utara Musafir Masudi (916) dan Battuta (abad XIV) meneliti keadaan orang-orang muslim dan mas jıdmasjid di pantai barat (permukiman muslim). Hasil penelitiannya dapat disımpulkan bahwa agama Islam telah disiarkan secara bergasrah di dekat Trichinopoly pada abad X) (lihat Nilakanta Sastri 1966 439)

Argumentasi tersebut menımbulkan pertanyaan apakah tidak mungkin Islam dı Indonesıa juga berkembang dari India Selatan. Apa lagı india Selatan letaknya lebih dekat dengan Indonesia (Sumatra) setidaknya secara langsung kedua tempat itu (Malaka dan Sumatra) dekat dari pada Guzerat ke Arabia, selain itu India-Indonesıa mempunyai hubungan dagang sejak lama. Argumentasi lain adalah mazhab yang dianut musiım Indonesia. Maxhab yang berkembang di Indonesia adalah syafi'i yang juga dianut oleh muslım dari India Selatan; sedangkan di India Utara golongan muslim menganut mazhab Hanafi. Demı-

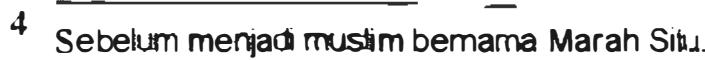


kıan pula kałau perıalanan agama Islam dikembalikan pada basis Tiongkok yang kemudian ber. gerak ke selatan, ke Sumatra dan Malaka. Hal ini juga akan terbentur pada masalah mazhab sebab muslim di Tiongkok pun menganut mazhab Hanafi. Memang mazhab Syafi'i dapat dirunut ke Hadramaut, juga ke Mesir, dan tempat lain di Timur Tengah (Juynboll 1930:20). Tempat terakhir itu (dalam hal ini Parsi) akan tampak menonjol dalam kaitannya dengan metoda awal belajar mengaji dı Indonesıa, khususnya di Jawa

Pendapat tentang basis islamisasi dari india Selatan, dan india Barat tidak berasal dari satu dua orang. Robson mengutip beberapa tokoh yang berpendapat seperti itu (lihat Java at the Clossroads, BKI 137:273- 274) Marrison (1951) bersiteguh bahwa penyebaran Islam ke Indonesia diawali dari India Selatan. la tidak sendiri saja sebab jauh sebelumnya, Snouck Hurgronye menyatakan "Ini sungguh mungkin bahwa Aceh sebagaı mana negeri lasnnya di Ned-Indie diislamkan darı Hindoustan. Bukan saja orang-orang Keling muslim dan orang-orang dari Madras dan Malabar melaınkan juga orang-orang Keling kafir, Chetties, dan orang-orang Hindu laınnya telah membuka pernıagaan dengan Aceh sampai sekarang (1906.117). Meskipun Crawfurd mempercayaı asal-usu! Islam di Indonesia dari Arabia, tetapı setelah mengamati budaya Melayu, kemudian ia berkesimpulan memang tuan-tuannya dari Arabıa tetapı pelaksananya adalah kaum muslim dari Pantas Timur India (182011:260) Kemudian Veth (Java 1 .. 1876-1923:231) dan pengikutnya, Arnold (1913:368) memandang lebih khusus tentang kedatangan agama Islam di Indonesia yaitu darı Pantal Malabar. Sedangkan komentar terbaru dikemukakan oleh R. Hall, bahwa islam indonesıa datang darı Pantaı Coromandel (1977: 222)

Bagaımana kemungkinan islam Indonesia dibawa dari Cina? Memang ada bukti-bukt keberadaan Cına Muslim dı Jawa pada abad XV sepertı dilaporkan oleh Ma-Huan yang juga seorang muslım dalam Ying-Yai-Shenglan yang terbit pada tahun 1433. Kata Na-Huan, "Negeri itu terdirı atas 3 kelas penduduk. Satu kelas terdiri atas penduduk muslim, mereka semua berasal dari negerı barat yang bermigrasi ke negeri ini sebagai saudagar yang dalam semua hal mengenakan pakaıan dan memakan makanan yang bersih dan terhormat Satu kelas terdiri dari penduduk Tang, semuanya datang dari Chang(chou) dan Chu'an(chou) dan tempat lain. Mereka pelarian dan banyak yang memeluk agama Islam dengan menjalankan ibadah dan berpuasa Satu kelas terdirı atas penduduk pribumi; mereka sangat bodoh dan wajahnya asing " (lihat Mill
1970:73; lihat pula, Groeneveidt 1876 VBG 39 49). Ma-Huan secara khusus menyebut dirınya penduduk Tuban dan Gresık sedangkan orang orang Cina Muslim itu tıdak disebut di mana tempat tinggainya. Tetapı Groeneveldt mengınterpretasikan ketiga kelas penduduk itu terdapat di Majapahit, jadi di pedalaman. Naskah Kidung Sunda yang ditulis di Bali pada abad XIV bahkan menyebutkan bahwa di Majapahit sudah ada Me sigit Agung (lihat Suwedi Montana, Sebuah tekateki Mesigit Agung di lbukota Majapahit. Kebudayaan No.4 Th. 11 1992/1993:51-56) Rupanya orang Cina telah tinggal lama di Jawa. Sejarah Islam di Cina Selatan memang panjang dan bag Ma-Huan apa yang dilaporkan itu pasti serıus tetapi seperti apa yang telah diungkapkan bahwa Muslim Cina itu penganut Mazhab Hanafi sehing ga tidak akan ada sejarah tentang kedatangan agama Islam di Jawa itu dibawa oleh mubalıgh. mubaligh darı Cina

\section{Pertimbangan Budaya}

Faktor budaya juga dapat menjadi indıkator dalam syiar agama Islam di Nusantara. Darı seg bahasa kita dapatkan banyak kata yang erat kaitannya dengan agama Islam di Indonesıa Pengaruh muslimın Tamil di Malaka selama abad 15 tampak jelas kalau kita menyımak Sejarah Melayu. Dalam Sejarah itu terdapat cırı-cırs yang bersifat Tamil terutama pada bidang tertentu Drewes misalnya mengungkap kenyataan bahwa kata lebai yaitu seorang pejabat yang ahli dalam agama Islam, berasal dari kata Tamil labbar ıalah nama kelompok muslim di india Selatan (1968 458-459). Dalam bahasa Jawa istilah lebaı menjadi lebe yaitu pejabat di desa-desa yang mempunyai tugas khusus mengurus agama Islam. Kata lain yang mempunyai kaitan langsung dalarr bidang ini adalah kata Melayu senterı yang mengacu pada kata Jawa santri. Kata senterı dalam sastra Melayu klasık sering digabung dengan kata 'dagang' menjadi 'dagang senteri' yang berart pedagang dan pelajar agama yang mengembara Sedangkan dalam bahasa Jawa kata santrı berarti siswa agama yang tinggal (mondok) di sekolah agama atau pesanten J Gonda telah membicarakan derivası kata-kata inı (lihat Sanskrit in Indonesia 1973:362-363). la mengaitkan kata itu dengan bentuk kata Sanskerta satri dari India Selatan yang artınya 'learned', 'schollar' tetapı tıdak. memperhatikan kata Tamı sattirı, malahan dikembalikan pada bentuk nomınatif Sanskeita sattri yang berart orang yang tinggal di suatu alms house. Padahal kata 'senten' dalam bahasa Melayu its boleh jadi justru dari kata 'santri' dalam bahasa Jawa jika dikaitkan dengan kata 'pe santren' sebab kata itu adalah istilah bahasa 
Jawa Dan jıka kata santrı daiam bahasa Jawa itu dikaıtkan dengan kata Tamıl sattirı akan mempunyai implıkası untuk sejarah institusi pesantren Kalau penelitian kita lebih menjurus pada masalah sastra dan aksara kelihatannya akan tejadi kecenderungan pergeseran tempat asal kedatangan agama Islam itu dari India Selatan ke Parsi Dalam hal inı Robson mengutip pendapat Lewis yang menyatakan bahwa huruf Melayu sebenarnya bukan huruf Arab melainkan modifikasi dari huruf Parsı. Ketika bangsa Parsi mengambil huruf Arab, mereka menemukan diakritik untuk melambangkan fonem c, 9, p, dan $\mathrm{zh}$, yang tidak terdapat dalam abjad Arab. Kemudian abjad Melayu mengambil $c$ dan 9, membuat fonem $p$ baru dari $f$. menemukan ng serta mengubah $p$ menjadi ny (Java at the Crossroads 181:238)

Dalam metoda pengajaran awal mengaji Quran pengaruh Parsı justru tampak sangat be-sar Sampal pada masa sebelum Perang Dunia 11 metoda awal membaca Quran mempergu-nakan diakritik yang jauh berbeda dengan kaidah gramatika bahasa Arab. Metoda itu oleh Hoesein Djajadiningrat dikatakan diadopsi dari Parsi; dan sampai saat ini masih dipraktekkan di desa-desa wilayah Banten Misalnya diakritik jabar untuk menghasilkan vokal a, menggantikan diakritik fatha; diakritik jer untuk menghasilkan vokal i dan e, menggantikan diakritik kasra dan diakritik pes untuk menghasilkan vokal o dan u, menggantikan diakritık damma. Dengan demikian seorang santri awal kalau mengeja abjad Arab, sebagai berixut,

alif jabar a bukan alif fatha - a

alif jer ı,e bukan alif kasra - 1,e

alif pes $0, u$ bukan alif damma - o, $u$

Demikian pula dalam nama-nama Jawa yang umumnya terdiri atas 3 suku kata maka kalau ditulis dengan huruf Pegon harus dieja dengan sistem tersebut, misalnya, sin labar = sa, ra jer $=n$, nun jabar = na $=$ Sarina

Dalam bidang sastra Melayu pun pengaruh Parsı tampak kuat. Kita lihat dalam Sejarah Melayu tentang bagaimana pada suatu malam menjelang serangan terakhir armada Portugis (1511), bangsawan-bangsawan muda Melayu berkumpul dı balairung. mereka berbincang-bincang. "Mengapa kita berdiam diri? Adalah baik sekali jika kita membaca kisah tentang peperangan sehingga dapat diambil manfaatnya". Mereka kemudian memohon kepada Baginda supaya meminjamkan Hikayat Muhammad Ibn Hanafiyah. Tetapi Bagında memberikan kepada mereka Hikayat Amir Hamzah. "Kıta akan memberi kamu Hikayat Muhammad Ibn Hanafiyah, kita tidak takut keberanian perwira-perwira istana cepat runtuh seperti keberanıan Muhammad Ibn Hanafiyah", kata Ba- ginda, "Tetapi barangkalı keberanıan kamu harus seperti Amir Hamzah maka darı itu kita memberı kamu Hikayat Amır Hamzah". Mereka tidak puas dengan hal itu dan mohon sekali lagi kepada Baginda yang kemudian memberikan Hikayat Muhammad ibn Hanafiyah (lihat Brown 1952 168). Kedua hikayat itu tidak terdapat dalam sastra Arab meiainkan terdapat dalam sastra Parsı. Dalam bahasa Jawa tokoh Amir Hamzah menjadı Amir Ambyah di dalam Serat Menak. Memang seperti menjadi tradisi dalam sastra Jawa dan sastra Melayu, bahwa sastra Jawa yang berkenaan dengan riwayat yang terdapat dalam Quran atau Al Kitab biasanya diadaptasikan dari sastra Melayu. Sebaliknya sastra Melayu yang berkenaan dengan riwayat yang berasal cerita-cerita berbahasa Sanskerta, disalin dari sastra Jawa

\section{Penutup}

Kasus sekitar kedatangan agama Islam ke Indonesia sudah sejak abad 19 diperbıncangkan oleh para pakar Para pakar Orientalis berpendapat bahw agama Islam datang ke Indonesıa terutama Sumatra, Malaka, dan Jawa, tıdak sama dengan pendapat para pakar Sejarah dan Agama Islam di Indonesia. Pihak Orientalis me. ngemukan bahwa kedatangan agama Islam di Indonesia itu melalui Guzerat, Coromandel, dan Timur Tengah terutama Parsı. Pendapat itu didasarkan atas berbagai argumentasi yang bersifat historis dan kultural. Dalam pada itu sebenarnya kalau kita menekuni historiografi lokal yang ditulis antara abad XVII-XX, terutama bab-bab yang berhubungan dengan riwayat Walisanga, akan mengetahui bahwa pengaruh Timur Tengah non Arab sangat kuat Misainya pengaruh Syeh Brahim (Ibrahim Ibn Adham dari Balkh, Irak) sangat dominan, selain itu juga pengaruh para Sufi darı Bagdad yang cenderung melontarkan ajaran wujudiyah telah dipraktekkan oleh Sitı Jenar dan Sunan Panggung yang sampai sekarang masih dianut oleh kelompok Muslım tertentu

Sebaliknya para pakar Indonesia abad $X X$ menyanggah pendapat para Orientalis itu sehingga sampai 3 kali diadakan semınar untuk meme cahkan masalah itu. Akumulasi kesimpulan keti. ga seminar itu, salah satu yang berhubungan de. ngan masalah kedatangan agama Isiam tersebut ialah, bahwa kedatangan agama Islam di indonesia dilakukan oleh para Mubaligh Arab dan langsung dari Tanah Arab. Pemyataan itu dengan dasar pertimbangan bahwa sejak abad Pertama Hijriyah orang-orang Arab sudah merantau ke tımur untuk berdagang, baik lewat darat atau pun lewat lautan. Pertimbangan lain ialah bagi orang Islam terdapat kewajiban untuk menyampaikan dakwah walaupun hanya satu ayat, sehıngga 
bagı para saudagar Muslim, hal itu sepert peribahasa sekali merengkuh dayung dua tiga pulau terlampaui. Tetapi pada dasamya para pakar ını hanya mengıngınkan purifikasi ajaran agama Islam sehingga pelaku dan basis penyiaran itu dikembalikan kepada asal agama Islam itu yakn Arabia, karena setelah berkembang ke timur agama Islam banyak terpenetrasi oleh unsur-unsur kepercayaan setempat, baik ketika masih di irak, Parsi, maupun setelah di India.

\section{KEPUSTAKAAN}

Azmı. Wan Hussein: 1981, Islam, masuk dan berkembangnya hingga abad XVI. Makalah dalam Seminar Sejarah Islam di Banda Aceh

Arnold,TW 1913,The Preaching of Islam.Lahore

Brown C C. 1952, Sejarah Melayu or Malay Annal. A translation of Raffles MS 18 JMBRASS XXV Part 2 \& 3

Cortesao Armando 1944, The Suma Oriental of Tome Pires. An Account of the East, from the Read Sea to Japan, written in Malaka and india in 1512-1515. London

Crawfurd J 1820, History of Indian Archipelago (3 vols.). Edinburgh.

Damais, L Ch 1954, Etudes Javanaises 1Le Tomdes Musulmanes Datees de Tralaya. BEFEO, Paris

Ojajadınıngrat, Hoesein, 1985, Tinjauan Kritik tentang Sejarah Banten, Jakarta

Groeneveldt.W.P, 1876, Notes on Malay Archipeiago and Malacca from Chinese Sources. V.B.G 39, 'S-Hage.

Guillot,Claude.L'Affiair de Zadrach, Archipel Parıs

Juınboll, TW, 1930, Handleiding tot de Kennis van Muhammedaansche Wet volgens de Leer der Sjafi'itische School. Leiden.

Marrison GE. 1951, The Coming of islam to East indies. JMBRASS 24.
Mill,J.V.G.,1970, The Overall Survey of Oceans Shores. Ma-Huan, Ying-Yai-Shengtan Cambridge

Robson,S.O.,1981, Java at the Crossroads. Aspects of Javanese Cultural History in the 14th and 15th Centuries. B.K.I. 137, 2e en 3 e Aflevering. 'S-Hage

Sastri, Nilakanta, 1966, A History of South India from Prehistoric Times to all of Wijayanagar, 3rd edn., Oxford. 